\title{
Neonomics
}

Central European Review of Economics \& Finance

Vol. 26, No. 4 (2018), pp. 5-24

DOI: $10.24136 /$ ceref.2018.018

Received: 21 July 2018. Accepted: 30 August 2018.

Alexandros G. SAHINIDIS ${ }^{1}$, Alina HYZ $^{2}$

\section{CSR ACTIVITY CONFIGURATION AND THE PRIORITIZING OF STAKEHOLDER CLAIMS: A MULTI-FIRM, MULTI-SECTOR STUDY ${ }^{3}$}

"I think we have a moral responsibility to help grow the economy, to help grow jobs, to contribute to this country and to contribute to the other countries that we do business in".

Tim Cook, CEO Apple Inc. Apple's Tim Cook Barnstorms for „Moral Responsibility” The New York Times August 28, 2017

The purpose of this study is to identify the patterns of Corporate Social Responsibility (CSR) activities, in adverse economic circumstances, so as to understand the importance ascribed by the companies to each of their stakeholders. Prior research on stakeholder salience has looked into various issues related to the relative attention given to corporate stakeholders by management, however, none has examined what this relationship looks like following a prolonged economic crisis. We investigate the activities of CSR in Greece, examining how companies spend their CSR resources in a depressed economy, studying the respective activity patterns of the companies listed on the Athens Stock Exchange (ASE). Content analysis is used, thoroughly examining all public data available on the internet from 175 companies. The study includes data reported in 2014, collected at the end of 2015. Our results demonstrate that, the most popular CSR activities related to the human resources and the least practiced were the society and environment related ones. The findings show concern for the employees of the companies and their morale, supersed-

\footnotetext{
${ }^{1}$ Associate Professor of Management at the University of West Attica, Athens, Greece.

${ }^{2}$ Professor of Management at the University of West Attica, Athens, Greece.

${ }^{3}$ An earlier version of this paper was presented at the $13^{\text {th }}$ Conference of the European Sociological Association 2017 in Athens, Greece.
} 
ing the interest for the other stakeholder categories in spite of the crisis and the soaring unemployment rate. Moreover, a significant divergence emerged between the CSR programs of the various industries. This indicates that for reasons unbeknownst to us, companies are placing less emphasis on consumers, environment and the society and tend to cater to the needs of their internal constituents.

Keywords: Stakeholders, Economic Crisis, Corporate Social Responsibility, Stakeholder Salience, CSR Activities, Greece.

JEL Classification Codes: M14, H12.

\section{Introduction}

Corporate social responsibility is one of the most researched areas in the business literature of the last two decades, especially following the corporate scandals at the beginning of the $21^{\text {st }}$ century (Enron, WorldCom, Parmalat, Bernie Madoff etc.). Responsible businesses, actual and self-proclaimed, in need of cost-cutting and reputation insurance, adopted CSR activities, seeking to build their brands and protect themselves from possible crises in the future, especially manifested in the aftermath of the 20072008 crisis (Shiu and Yang, 2017; Fehre and Weber, 2016; Minor and Morgan, 2011; Eisenegger and Schranz, 2011).

As a result of different approaches to the study of CSR, owed to the diverse background of scholars, the extant literature comes under several terms, with great overlaps in meaning among them (Aguinis and Glavas, 2012; Orlitzky et al. 2017; Mitchell et al. 2017). Carroll and Shabanna (2010) observe that: „The term „corporate social responsibility" is still in popular use, even though competing, complementary and overlapping concepts such as corporate citizenship, business ethics, stakeholder management and sustainability are all vying to become the most accepted and widespread descriptor of the field... however, all these concepts are related, in that they are integrated by key, underlying themes such as value, balance and accountability." (p. 86)

The multiple approaches to the study of CSR resulted to a lack of a universal definition of it. CSR may be defined as a concept or a tool, used by companies at the stage of strategy building, whereby they voluntarily take into account the interests of society and environmental protection, as well as relationships with various stakeholder groups. Being responsible means not only fulfilling all formal and legal requirements, but in addition increasing investment in human resources, society, environment, which is a voluntary commitment. Corporate responsibility is part of management strategy, which through social dialogue at the local level, contributes to the competitiveness of companies on a global level and at the same time helps drawing the trajectory for sustainable social and economic development. A Business by definition aims to make a profit, takes ac- 
tions on behalf of many (if not all) of its stakeholders, treating such activities as an investment that lead it to the achievement of its objective, while taking care of the interests of all parts of the environment of the company. For the purposes of this study Carroll's early definition of CSR will be used, since it is encompassing all main subthemes of the concept, and it is also one of the most commonly used in the literature. According to Carroll (1979): „The social responsibility of business encompasses the economic, legal, ethical, and discretionary [later referred to as philanthropic] expectations that society has of organizations at a given point in time." (p. 500).

The deep economic crisis that afflicted Greece is reflected, inter alia, in the main macroeconomic ratios, like Gross Domestic Product and unemployment and some indicators of the banking sector, like deposits, total loans and non-performing loans (NPLs). Between 2008 and 2014 the Greek Gross Domestic Product decreased more than 25\%, (http://www.statistics.gr/el/statistics/-/publication/SEL24/-) while unemployment increased from $7.8 \%$ in 2008 , to a high of $27 \%$ (http://www.statistics.gr/ documents/20181/007b1bab-7cad-4df3-81f1-5b18c76770ce).

Greece is characterized today by borrowing problems, high public debt, serious lack of competitiveness, unsustainable social security system, particularly poor public administration and a large inefficient public sector. With real GDP in 2014 almost 25\% below its 2008 level, Greek firms have borne the brunt of the economic crisis in recent years. The protracted economic crisis decreased firms' profitability and increased the need of finding ways to gain funds.

The purpose of this study is to identify the patterns of Corporate Social Responsibility (CSR) activities, in adverse economic circumstances, so as to understand the importance ascribed by the companies to each of their stakeholders. In particular, we examine how the companies listed on the Athens Stock Exchange (ASE) spent their CSR resources during 2014, the sixth year into the crisis. In this study, we provide a comprehensive view of the public companies' full spectrum, addressing the activities and the emergent patterns of CSR, as they derive from the websites of the entirety of the organizations listed on the ASE. Using stakeholder theory (Freeman, 1984; Orlitzky et al. 2017; Michell et al. 1997; Weitzner and Deutsch, 2015), this study attempts to identify which stakeholders rank high in the corporate priorities and which are secondary ones, in a six-year long economic crisis environment (Thijssens et al. 2015; Weitzner and Deutsch, 2015; Neville et al. 2011). The stakeholder salience approach has not been studied in the context of a long-lasting crisis and to that extent this will be the contribution of this study. We investigate what the industry CSR practices look like, following six years of economic recession, high unemployment and socio-political upheaval, characterizing Greece, since 2008. We try to answer the following questions: - How do companies spend their CSR resources in a depressed economy, with many stakeholders making claims on those resources? 
- Are there any differences between industries in terms of their responses to their stakeholder demands?

The paper is organized as follows: in the next section we review the literature on the subject. In section three we present the research methodology and the data sources used in the analysis. The results are presented and discussed in section four. In the last section, we present conclusions and directions for further research.

\section{Literature review}

There is a vast literature describing different aspects of corporate social responsibility. Aguinis and Glavas (2012) in their review included 588 articles, both conceptual and empirical since the 1970's. Many of the studies initially focused on CSR antecedents, moving on, scholars examined the related outcomes while more recently, the focus has shifted to processes involving CSR within organizations (Wang et al., 2016). A large number of scholars focused on the influence of CSR on variables such as financial performance (Orlitzky et al. 2003; Wang et al. 2015; Taghian et al. 2015; Ni et al. 2015; Nag and Bhattacharyya, 2016), client or employee perception (Reklitis et al. 2018; Anadol et al. 2015), firm's reputation, innovation and learning, access to capital, risk reduction, productivity increase etc.

In a large study with samples from three countries: China, Hong Kong and Taiwan, $\mathrm{Ni}$ et al. (2015), examined the hypothesis that different types of CSR activity configurations, could lead to different financial performance. The authors reported that high levels of CSR activities targeted at primary stakeholders (customers, employees and investors), were associated with high performance. Also, they found that their conclusions were consistent in all three countries they studied, in terms of the configurations of the activities discussed. Porter and Kramer $(2011,2006)$, posited that addressing its other constituencies, along with its shareholders, will lead a company to sustainable high performance through the creation of shared value. Other studies focused on the impact of CSR on internal organizational aspects such as employee commitment, satisfaction, turnover rate, etc. (Chang et al. 2016; Yoon and Lee, 2016). Rupp et al. (2006) and Fukukawa et al. (2007) demonstrated the impact of corporate social responsibility activities on the level of trust in the organization and, consequently, on employees' attitudes and behavior. Kim et al. (2010) found that CSR activities affect the degree of employee identification with the company, and Brammer et al. (2007) that they correlate positively with employee involvement.

Some researchers focused on the investor's attitudes towards socially responsible companies, positing that investment companies, especially institutional investors demonstrate a proclivity to invest in companies with a proven record of long term thinking, part of which is being socially responsible and responsive to the calls of a company's 
stakeholders (Cordeiro and Tewari, 2015; McKinsey, 2016; BCG, 2016). Two of the most fervent opponents of CSR, Friedman, (1970) and Leavitt, (1958), proposed that the goal of a business is to make profit for the shareholders and not to complement the state by remedying the deficiencies of the public sector. In another line of research, Fehre and Weber, (2016), studied management attitudes toward CSR in times of crisis, concluding that CEOs of German public companies tend to talk less about social and governance issues, in their public statements, indicating a lessening of interest on CSR or at least, a lack of consistency in their interests for the specific years, before and after the crisis. Finally, Orlitsky et al. (2017) studied the impact variation of the influence of the National Business Systems (NBS), the industry effects and those of organizational variables, on corporate social performance (CSP), a concept overlapping with CSR (Carroll and Shabanna, 2010; loannou and Serafim, 2012; Schwartz and Carroll, 2008). The authors concluded that although much more research is needed, their exploratory study showed that the role of company - level variables is greater than that of NBS and of the industry (Orlitzky et al. 2017; Matten and Moon 2008). A large part of the literature is devoted to customer CSR related perceptions and company reputation issues (Du et al. 2010; Chaudhary, 2017).

As the research on CSR progresses, the literature is moving in the direction of examining specific CSR activities and measures rather than the aggregate social performance of organizations (Wang et al. 2016; Mitchell et al. 2017; Peloza and Papania, 2008).

Table 1 provides an overview of some recent studies of corporate social responsibility which are important from the point of our research.

Table 1. Corporate social responsibility - research review

\begin{tabular}{|l|l|}
\hline \multicolumn{1}{|c|}{ Researcher(s) } & \multicolumn{1}{c|}{ Findings } \\
\hline Holcomb et al. (2007) & $\begin{array}{l}\text { This study used as a sample the top ten hotel companies as listed in Hotels maga- } \\
\text { zine. The findings reveal that: } 80 \text { percent of the companies analysed reported so- } \\
\text { cially responsible activities relating to some form of charitable donations, } 60 \text { percent } \\
\text { reported a diversity policy, and } 40 \text { percent provided some mention of SR in their } \\
\text { vision or mission statements. Some companies were highly focused on providing } \\
\text { a balanced approach to SR while other hotel companies were less focused in their } \\
\text { efforts. The areas of SR that seemed to be lacking with regards to reporting were } \\
\text { environmental, and vision and values. }\end{array}$ \\
\hline Matten and Moon (2008) & $\begin{array}{l}\text { The authors examined the historical evolution of CSR in the USA and in Europe. } \\
\text { Their conclusions include: 1. The National Business System plays a role in the differ- } \\
\text { ing manifestations of CSR, contributing to the variations seen in many countries. 2. } \\
\text { The differences in political, social, cultural and economic institutions lead to different } \\
\text { approaches to CSR, an explicit one in the USA and an implicit one in Europe. The } \\
\text { authors conclude that the European countries increasingly tend to adopt the explicit } \\
\text { approach converging with the US business practices. }\end{array}$ \\
\hline
\end{tabular}




\begin{tabular}{|c|c|}
\hline Researcher(s) & Findings \\
\hline Achua, (2008) & $\begin{array}{l}\text { This paper investigates the corporate social responsibility in Nigerian banking sector } \\
\text { and identifies the following major constraints to the adoption of CSR: regulatory lax- } \\
\text { ity, inauspicious macro-economic environment, endemic corruption and self-induced } \\
\text { vices. }\end{array}$ \\
\hline Smith (2008) & $\begin{array}{l}\text { In this study the author is using two case studies from the pharmaceutical industry } \\
\text { (GSK and BC) indicating why companies must implement CSR principles in their } \\
\text { strategies with emphasis on brand name building and company awareness towards } \\
\text { consumers. }\end{array}$ \\
\hline Aras et al. (2010) & $\begin{array}{l}\text { This paper aims to investigate the relationship between corporate social responsibil- } \\
\text { ity and firm financial performance in developing countries using as a sample } 100 \\
\text { companies from Istanbul Stock Exchange (ISE). In doing this analysis the authors } \\
\text { found a relationship between firm size and corporate social responsibility. However } \\
\text { the authors were unable to find any significant relationship between corporate social } \\
\text { responsibility and financial performance/profitability. }\end{array}$ \\
\hline Vitaliano, (2010) & $\begin{array}{l}\text { This paper aims to estimate empirically the effect on the voluntary turnover (quit) } \\
\text { rate of employees when a large public corporation already judged as an outstand- } \\
\text { ing employer is also ranked as being socially responsible by an external review } \\
\text { organization. The researcher used as a sample } 84 \text { of Fortune magazine's " } 100 \text { Best } \\
\text { Employers". According to the findings these firms reduce the annual quit rate by } \\
2530 \text { percent as compared to non CSR public corporations or a larger comparison } \\
\text { set including privately held and not for profit firms. }\end{array}$ \\
\hline Ferreira, (2010) & $\begin{array}{l}\text { This study show that consumers perceived greater benefit and value in the offer of } \\
\text { the socially responsible firm, and were showed to be willing to pay } 10 \text { percent more } \\
\text { for its product, judging this price differential as being fair. Moreover, the social action } \\
\text { with direct impact on the consumer's life influenced more positively his/her reactions } \\
\text { than the social action with indirect impact. }\end{array}$ \\
\hline $\begin{array}{l}\text { Mandhachitara } \\
\text { and Poolthong, (2011) }\end{array}$ & $\begin{array}{l}\text { This study demonstrated that CSR has a significant strong and positive association } \\
\text { with attitudinal loyalty. Perceived service quality mediated the relationship between } \\
\text { CSR and repeat patronage intentions (behavioural loyalty). Direct effects were } \\
\text { reported between perceived service quality and both attitudinal and behavioural } \\
\text { loyalty. }\end{array}$ \\
\hline Chen and Wang, (2011) & $\begin{array}{l}\text { The results of this study show that companies' social responsibility activity can im- } \\
\text { prove their financial performance of the current year, have significant effects on their } \\
\text { financial performances of the next year, and vice versa. The variation of CSR and } \\
\text { financial performance can also significantly influence each other. }\end{array}$ \\
\hline Al Naimi et al. (2012) & $\begin{array}{l}\text { The research using the sample of Qatari companies listed on the Qatar Exchange } \\
\text { finds that most companies disclosed information related to human resources and } \\
\text { product development, followed by community involvement. No company reported } \\
\text { environmental issues in their annual report. }\end{array}$ \\
\hline Mozes et al. (2012) & $\begin{array}{l}\text { This paper presents the positive significant correlations between organizational } \\
\text { identification, volunteering, job satisfaction and motivation and CSR engagement. } \\
\text { Significant differences were also found between active participants in the company's } \\
\text { CSR programs and non-participants on organizational identification and motivation, } \\
\text { but not for job satisfaction. }\end{array}$ \\
\hline
\end{tabular}




\begin{tabular}{|c|c|}
\hline Researcher(s) & Findings \\
\hline Rakotomavo (2012) & $\begin{array}{l}\text { This research supports the hypothesis that mature firms tend to invest more in CSR. } \\
\text { Specifically, firms investing highly in CSR tend to be larger, more profitable, and } \\
\text { with greater earned equity. The evidence also supports the hypothesis that CSR } \\
\text { investment does not subtract from dividends. Instead, CSR effort and dividend tend } \\
\text { to increase together. }\end{array}$ \\
\hline Ni et al., (2015) & $\begin{array}{l}\text { In a large study with samples from three countries, the authors examined the hy- } \\
\text { pothesis that different types of CSR activity configurations, could lead to different } \\
\text { financial performance. The authors reported that high levels of CSR activities target- } \\
\text { ed at primary stakeholders (customers, employees and investors), were associated } \\
\text { with high performance. Also, they found that their findings were consistent in all three } \\
\text { countries they studied, China, Hong Kong and Taiwan, in terms of the configurations } \\
\text { of the activities discussed. }\end{array}$ \\
\hline Wang et al., (2015) & $\begin{array}{l}\text { In a meta-analysis of } 119 \text { samples from } 42 \text { studies the authors reported an unshake- } \\
\text { able positive relationship between CSR and Financial Performance. Furthermore, } \\
\text { testing for causality, they found that the relationship was found only when CSR pre- } \\
\text { ceded performance, while the reverse did not hold true. }\end{array}$ \\
\hline Orlitzky et al. (2017) & $\begin{array}{l}\text { The study examines the relationship between Corporate Social Performance (CSP) } \\
\text { and three levels of variables, at the macro level (country), the meso level (industry) } \\
\text { and micro level (firm). They report a strong relationship of country related variables } \\
\text { with the shareholder dimension of CSP, while the overall CSP, the community, the } \\
\text { environment and the employee dimensions related to company level variables. }\end{array}$ \\
\hline $\begin{array}{l}\text { Mitchell, Lee and Agle } \\
\text { (2017) }\end{array}$ & $\begin{array}{l}\text { The authors discuss the new findings reported in the literature on the stakeholder } \\
\text { salience model, or alternatively as the "stakeholder prioritization work." Mitchell } \\
\text { et al., present the recent research categorizing it in five streams, as proposed by } \\
\text { Lee (2015), Lee included five work domains in his model: stakeholder awareness, } \\
\text { stakeholder identification, stakeholder understanding, stakeholder prioritization, and } \\
\text { stakeholder engagement. }\end{array}$ \\
\hline
\end{tabular}

Source: Own summary based on the literature review.

Among the research streams in CSR, the stakeholder salience framework stands out. Freeman $(1984$, p. 46), defined stakeholder as „any group or individual who can affect or is affected by the activities of the organization's objectives". The need for the study of stakeholder salience arose due to lack of understanding of the impact of individual CSR activities on organizational outcomes. Earlier CSR studies failed to discriminate the specific dimensions of CSR, when making the connection between overall Corporate Social Responsibility and Financial performance or Reputation (Wang et al. 2016). The issue of identifying the importance of each of the corporate stakeholders was introduced in the relevant discourse by Mitchell et al. (1997) and discussed further in the latest work by Mitchell et al. (2017). Mitchell et al. (1997) suggested that "not all stakeholders are created equal" and there are three attributes that affect their salience to an organization, the Power, the Urgency and the Legitimacy of their claims. These three attributes 
determine, the authors intimated, the priority given to the stakeholder claim, resulting in corresponding actions by the company when making resource allocation decisions. In this framework the context of the present study is unique, due to the changes in the socioeconomic environment, which are expected to have affected the power, the urgency and legitimacy of the stakeholder claims and the respective corporate behaviour thereof. The stakeholder salience theory considers how an organization's stakeholder relationships interact to generate maximum value in an ethical manner (Beckam et al. 2016; Mitchell et al. 1997). The stakeholder salience framework has received considerable support by several scholars examining the prioritization of stakeholders (Weitzner and Deutsch, 2015; Thijssens et al., 2015; Guerci and Shani, 2013; Magness, 2008). However, the stakeholder salience framework has also been critiqued as being largely static, short-term-oriented, firm-centred, needing both enrichment with more attributes and the establishing of different potency of each of those (Baba and Raufflet, 2017; Beaulieu and Pasquero, 2002; Neville et al., 2011). The issue of the model's dynamism is relevant to our study, since the attributes that provide impetus to a stakeholder group claim, may change if there is a disruption in the corporate state of affairs, or its environment, making another stakeholder group claims more legitimate, urgent or hard to resist. While for example, a company normally contributes to environmental causes or to philanthropy, in a crisis period, management may be more inclined to direct company resources to more powerful stakeholders such as customers, or try to lessen the impact of the crisis on shareholders or employees, diverting the precious resources to them, instead of the relatively powerless environmental and philanthropic causes.

A growing body of literature emphasizes the role of social responsibility for the firm, albeit almost all the above mentioned studies aim to investigate the corporate social responsibility activities during non-crisis periods. Some researchers investigated CSR in crisis periods, in terms of its relationship to financial performance, perceived effects on company reputation and the cost-containment management actions leading to smaller CSR budgets (Diaz-Pont, 2017; Metaxas, and Tsavdaridou, 2013; Karahibraimoglou, 2010; Placier, 2011; Souto, 2009). A study by Garcia-Benau et al. (2013), examining the economic crisis in Spain, concluded that "in times of crisis companies perceive CSR reporting and assurance as a valuable investment in spite of its costs" (p. 1539). Dias et al. (2016) has investigated the evolution and extent of CSRD, before and during the last financial crisis, for 36 listed Portuguese companies. In terms of general disclosure pattern during the crisis period, Portuguese listed companies were more concerned about their involvement with society, particularly in matters of corruption prevention and community affairs. Previous studies of CSR, among Greek companies, have partially shed light to relevant corporate activities in Greece during crisis, however the samples used were rather small, presenting a minute part of the big picture (Giannarakis and Theotokas, 2011; Sahinidis and Kavoura, 2014; Kavoura and Sahinidis, 2015; Sahinidis et al. 2018; Reklitis et al. 2018). Other relevant studies, examined only the early part 
of the economic crisis, when its sheer size was not evident and had still little impact on CSR-related company decisions (Giannarakis and Theotokas, 2011). Karagiorgos (2010) examined a sample of Greek companies with CSR programs, before the economic crisis, reporting a causative positive relationship between CSR and financial performance. Our study tries to investigate the issue of CSR activity configuration and the prioritizing of stakeholder claims, following a protracted crisis period on a large scale.

\section{Methodology and data collection}

We use data from all Greek firms listed on the Athens Stock Exchange in 2014 making CSR disclosures. We collected data from the web pages of 175 companies, and other public sources such as the business press and CSR related organizations. No information was available on CSR activities by 31 companies. The companies we examined represented 19 sectors (Table 2).

Table 2. ASE Listed Companies (as of Jan. 2015)

\begin{tabular}{|l|c|}
\hline \multicolumn{1}{|c|}{ Sector } & $\begin{array}{c}\text { Number of companies } \\
\text { in sector's sample }\end{array}$ \\
\hline Banks & 7 \\
\hline Chemicals & 5 \\
\hline Construction and Construction Materials & 19 \\
\hline Energy & 1 \\
\hline Financial Services & 4 \\
\hline Food and Beverage & 20 \\
\hline Health & 6 \\
\hline Industrial Products and Services & 19 \\
\hline Insurance & 1 \\
\hline Media & 6 \\
\hline Oil and Gas & 3 \\
\hline Personal and Household Goods & 20 \\
\hline Raw Materials & 15 \\
\hline Real Estate & 6 \\
\hline Services of General Interest & 4 \\
\hline Technology & 17 \\
\hline Telecommunications & 1 \\
\hline Trade & 7 \\
\hline Travel & 14 \\
\hline
\end{tabular}

Source: The authors' own calculations. 
We use quantity content analysis as research method. It is a research technique widely used to analyse the text messages, both written (books, newspapers, documents, web pages) and oral (for example distributed by radio and television). Content analysis is typically used in qualitative studies, allowing though some quantitative analysis such as frequencies (Cascio and Aguinis, 2008). Berelson (1952) defined content analysis as „a research technique for the objective, systematic and quantitative description of the manifest content of communication". The aim of this method is to reduce the content of the whole text to the most important meanings: the most frequently occurring words, key themes, prevailing forms of grammatical and semantic etc. We implement this method in three main phases: 1. preliminary analysis, 2. processing of the material tested and 3 . analysis of results containing the interpretation and conclusions. During these we selected and categorized firms. Then, we chose the main dimension of social responsibility. We investigated the web site of each company using key words for the analysis. In the few cases where we were unable to locate the information needed we decided to contact directly the company to be able to obtain the necessary information. Following the work by Holcomb et al. (2007), Giannarakis and Theotokas, (2011) and Kavoura and Sahinidis, (2015), the following dimensions of CSR were used in this study: (1) Society, (2) Environment, (3) Marketplace, (4) Employees, (5) Vision, Values and Corporate Governance.

Our intent of this study is threefold:

1. To find out the choices of company activities of CSR during the year investigated.

2. To discern the differences between sectors.

3. To inquire the level of interest of firms in CSR beneficiary groups.

Our first step was to investigate the actions and activities carried out by each company for each dimension of CSR (Table 3). In this way we manage to present in a few words each action. Our next step was the use of more succinct descriptions of the CSR activities of each company. This allowed us to easily and quickly understand what CSR areas and actions are undertaken in each sector and which groups of companies have undertaken more action. Searching and classification of CSR actions on business reports proved an arduous process. As a result we obtained a number of 2999 CSR activities reported on the companies' web sites (including the few documents we accessed through direct contact with some companies). 
Table 3. CSR Activity Categories

\begin{tabular}{|l|l|}
\hline Society & $\begin{array}{l}\text { Charitable donations, Community welfare, Corporate giving, Donations } \\
\text { in kind, Education, Grants, Water conservation, Local regeneration, } \\
\text { National welfare, Volunteerism, World welfare }\end{array}$ \\
\hline Environment & $\begin{array}{l}\text { Cultural heritage, Energy management, Pollution control, Relationship } \\
\text { with customers, Recycle, Waste management, Self-regulation, Re- } \\
\text { source consumption }\end{array}$ \\
Water and soil releases, Product impact \\
\hline Marketplace & $\begin{array}{l}\text { Ethical advertising, Providing a product of value, Relationship w/suppli- } \\
\text { ers, Relationship with shareholders, }\end{array}$ \\
\hline Employees & $\begin{array}{l}\text { Advancement, Fair and equitable benefits, Career planning, Compen- } \\
\text { sation and rewards, Daycare and family accommodations, Diversity/ } \\
\text { equal opportunity, Employee assistance program, Employee commu- } \\
\text { nication, Health and safety, Recruitment, Training, Forced and Child } \\
\text { labor, Freedom of association, Right to organize }\end{array}$ \\
\hline $\begin{array}{l}\text { Vision, values and Corporate } \\
\text { Governance }\end{array}$ & $\begin{array}{l}\text { Accountability, Clear purpose, Code of conduct, Enduring values, Ethi- } \\
\text { cal behavior, Fairness, Trust, Independence of directors, }\end{array}$ \\
Audit committee, Executive Compensation and remuneration \\
schemes, Voting rights \\
Anti-takeover devices
\end{tabular}

Source: The authors' own compilation.

\section{Results and Discussion}

Previous studies have shown that different types of CSR activities elicit different responses from the company stakeholders (Orlitzky et al. 2003; Peloza and Shang, 2011), with the former reporting a stronger correlation of donation giving to financial performance than the one of environment related activities. Peloza and Papania (2008) propose that the evaluations of different CSR activities from both salient and non-salient stakeholders constitute one reason for the conflicting findings on the relationship between CSR and firm financial performance.

It is expected then that different configurations of CSR activities will have a varying impact on organizational outcomes and scholars will need to shed light on the dynamics of this activity-outcomes relationship. Although this study does not examine organizational outcomes, it provides a lucid picture of the priorities of the public companies in ASE, in disbursing their CSR budgets both individually and in industry terms.

We present the results of the measure of the extent of CSR practices in the sample in Table 4. In order to enable direct comparisons between sectors the ratio "CSR' activities by firm" was calculated. The data show that most CSR actions are reported in the 
following sectors: Telecommunications, Oil and Gas, Insurance and Banks. While the lowest activity rate appeared in: Trade, Construction and Construction Materials and Chemicals.

Table 4. Number of CSR activities by sector and firm

\begin{tabular}{|l|c|c|}
\hline \multicolumn{1}{|c|}{ Sector } & $\begin{array}{c}\text { Total number of CSR activities } \\
\text { in sector }\end{array}$ & $\begin{array}{c}\text { Number of CSR activities } \\
\text { by firm in the sector* }\end{array}$ \\
\hline Banks & 214 & 30.6 \\
\hline Chemicals & 58 & 11.6 \\
\hline $\begin{array}{l}\text { Construction } \\
\text { and Construction Materials }\end{array}$ & 149 & 7.8 \\
\hline Energy & 21 & 21.0 \\
\hline Financial services & 107 & 26.8 \\
\hline Food and Beverage & 307 & 15.4 \\
\hline Health & 122 & 20.3 \\
\hline Industrial products and services & 399 & 21.0 \\
\hline Insurance & 33 & 33.0 \\
\hline Media & 113 & 18.8 \\
\hline Oil and gas & 139 & 46.3 \\
\hline Personal and Household goods & 433 & 21.7 \\
\hline Raw Materials & 205 & 13.7 \\
\hline Real Estate & 65 & 10.8 \\
\hline Services of general interest & 62 & 15.5 \\
\hline Technology & 186 & 10.9 \\
\hline Telecommunications & 58 & 58.0 \\
\hline Trade & 47 & 6.7 \\
\hline Travel & 281 & 20.1 \\
\hline
\end{tabular}

* Number of CSR activities by firm in the sector = Total number of CSR activities in sector/ Number of companies in sector's sample

Source: The authors' own calculations.

In Table 5 we show the breakdown of the number of various content category themes by industrial sector.

Corporate social responsibility can be considered in the external dimension - it is the activity addressed mainly to the customers or the environment, and in the internal dimension - it is an activity addressed to employees. 
Table 5. Number of CSR content category themes by sector

\begin{tabular}{|l|r|r|r|r|r|r|}
\hline \multicolumn{1}{|c|}{ Sectors } & Society & Environment & Market & Employees & $\begin{array}{c}\text { Vision, Values } \\
\text { and Governance }\end{array}$ & Total \\
\hline Banks & 41 & 54 & 37 & 49 & 33 & $\mathbf{2 1 4}$ \\
\hline Chemistry & 3 & 10 & 9 & 19 & 17 & $\mathbf{5 8}$ \\
\hline $\begin{array}{l}\text { Construction } \\
\text { and Construction Materials }\end{array}$ & 20 & 25 & 26 & 39 & 39 & 149 \\
\hline Energy & 8 & 3 & 4 & 1 & 5 & 21 \\
\hline Financial services & 38 & 11 & 20 & 16 & 22 & 107 \\
\hline Food and Beverages & 39 & 42 & 62 & 81 & 83 & $\mathbf{3 0 7}$ \\
\hline Health & 42 & 9 & 20 & 23 & 28 & 122 \\
\hline Industrial Products and Services & 56 & 64 & 77 & 106 & 96 & 399 \\
\hline Insurance & 13 & 6 & 3 & 5 & 6 & 33 \\
\hline Media & 21 & 16 & 18 & 34 & 24 & 113 \\
\hline Oil and gas & 16 & 38 & 21 & 32 & 32 & 139 \\
\hline Personal and Household Goods & 65 & 68 & 84 & 112 & 104 & 433 \\
\hline Raw Materials & 34 & 50 & 27 & 56 & 38 & $\mathbf{2 0 5}$ \\
\hline Real Estate & 15 & 13 & 9 & 10 & 18 & 65 \\
\hline Services of Common Interest & 8 & 15 & 12 & 15 & 12 & $\mathbf{6 2}$ \\
\hline Technology & 43 & 21 & 39 & 42 & 41 & 186 \\
\hline Telecommunication & 5 & 19 & 9 & 19 & 6 & $\mathbf{5 8}$ \\
\hline Trade & 10 & 5 & 15 & 5 & 12 & $\mathbf{4 7}$ \\
\hline Travel & 48 & 43 & 50 & 70 & 70 & $\mathbf{2 8 1}$ \\
\hline Total & $\mathbf{5 2 5}$ & $\mathbf{5 1 2}$ & $\mathbf{5 4 2}$ & $\mathbf{7 3 4}$ & $\mathbf{6 8 6}$ & $\mathbf{2 9 9 9}$ \\
\hline
\end{tabular}

Source: The authors' own calculations.

The results of our research were rather surprising to us. Contrary to our expectation for the domination of society-related CSR practices (external dimension), employees appear to be the leading stakeholder capturing the attention of management (internal dimension), assuming a bigger stake than the other constituencies of the organizations whether primary or secondary stakeholders. Employee-related CSR activities exceed any other category in 9 industries, while they are the second priority in another 4 industries of the total of 19 in the sample (Table 6). This would be intuitively compelling in an economy functioning under normal circumstances, but less so in a depressed economy, with unemployment rates in the high 20's and the society ravaged by it. The second most preferred category was society in 5 industries, while if we were to include the second priority, values, vision and governance would be first, but with only 4 industries as a first priority. These results are not far from the findings of earlier studies, which were conducted in totally different contexts nevertheless. Ni et al., (2015), found that CSR practices concerned with employees, customers and investors (the primary stakehold- 
ers), lead to high financial performance, as opposed to those addressing secondary stakeholder issues. The same authors claim that, although in Taiwan the employee CSR practices take precedence for the high performing companies versus customer CSR practices in Hong Kong, their key finding is that the determinant of the high company performance in their sample is the configuration of CSR practices and not those related to one stakeholder group.

Table 6. The top two Corporate Stakeholder Priority Rankings in 19 Sectors

\begin{tabular}{|l|c|c|c|c|c|}
\hline & Society & Environment & Marketplace & Employees & $\begin{array}{c}\text { Vision, values } \\
\text { and Governance }\end{array}$ \\
\hline First Priority in Number of Sectors & 5 & 3 & 1 & 9 & 4 \\
\hline Second Priority in Number of Sectors & 1 & 3 & 3 & 4 & 10 \\
\hline
\end{tabular}

Source: The authors' own calculations.

\section{Conclusions, Limitations and Implications for Further Research}

Earlier findings by Peloza and Shang (2011) lead to the conclusion that marketers' knowledge of stakeholder responses to specific CSR activities is rather limited. Given that most firms now engage in CSR activities, managers need a greater understanding of how different activities create differentiation, and how they can create a larger value proposition for stakeholders.

This study has investigated what the industry CSR practices look like, following six years of economic recession, high unemployment and socio-political upheaval, characterizing Greece, since 2008. We use data from 175 Greek firms listed on the Athens Stock Exchange in 2014, by means of a quantity content analysis of annual CSR disclosures. Our results demonstrate that, contrary to our expectations, the most popular CSR activities related to the human resources and the least practiced were the society and environment related ones. Employee-related CSR activities exceed any other category in 9 industries, while they are the second priority in another 4 industries of the total of 19 in the sample. This indicates that companies are placing less emphasis on consumers, environment and the society and tend to cater to the needs of their internal constituents.

\section{Limitations}

One limitation of this study stems from the fact that it is conducted in one country. In order to understand better the impact of financial crisis on Greek firms, the research could be extended by including more countries and more years in the crisis period. Research on comparative CSR practices indicates significant influence on corporate policy by cultural factors and National Business Systems (Matten and Moon, 2008; Orlitzky et al. 2017). Another limitation of this study is its cross-sectional nature, not 
allowing for more generalizable conclusions, since the CSR activity profiles generated may be due to circumstances present only in the years studied. A third limitation of the present research relates to the grouping of the CSR activities and the drawing conclusions on the groups rather than the individual activities. This may conceal the importance attributed by management to specific activities, while inflating the gravity of others. Moreover, although the number of activities is greater for the employee-related activities, other categories may be consuming resources of greater amounts, which is not reflected in our analysis. Finally, the study remains within the bounds of description of a phenomenon, providing no exegesis of it, not being making the link between CSR practices and organizational outcomes (Aguinis and Glavas, 2012).

\section{Implications and Future research}

The study provides useful insight to researchers, as well as business strategists, especially in countries facing problems similar to those of Greece, such as Spain, Portugal, Cyprus and potentially ltaly (Diaz-Pond, 2017; Skouloudis et al. 2014). Our analysis of the choices of actions in the field of social responsibility during the crisis indicates that the decision makers place a greater emphasis on employees. It may be explained by the efforts to increase their job satisfaction when the possibilities of using other incentives are limited. The crisis period is characterized by the increased uncertainty. One of the most important problems of Greek enterprises during the years of crisis is the loss of qualified staff, which is looking for the possibilities of employment abroad. Increased sensitivity to the human factor may be an effort to keep human resources in the business. When employees are the leading stakeholder capturing the attention of management, the incentive to leave their work places is limited, as the opportunity cost increases if they leave the company. Employees are a group of stakeholders that is crucial for the effective operation of a company, as it may constitute a source of firm's competitive advantage. Positive effects of socially responsible activities on employees are also strong, based on trust relationships with employees, increased motivation and loyalty of employees, greater integration, group cohesion and a good image within the company (Rupp et al. (2006), Fukukawa et al. (2007), Kim et al. (2010), Brammer et al. (2007)). According to research by Chaudhary (2017) employee-related CSR activities had the strongest impact on employee engagement at work.

Future studies can attempt to further delve into the dynamics of the CSR activity patterns leading to greater financial performance and overall organizational effectiveness. Assuming that there are industry and firm-specific differences, as to which CSR activities produce better outcomes, it would be an important contribution to strategists and policy makers, deciding on the optimal use of corporate resources. Although there is some research on the topic by Ni et al. (2015), and Orlitzky et al. (2017), more research is needed, considering the slow convergence rate between National Business Systems 
(assuming there is such convergence). Moreover, based on the findings of Ortlitzky et al. (2017), even if there is similarity in National and Industry level practices, the larger portion of corporate social performance is explained by firm-level variables and this necessitates the focus of research efforts more at the level of corporate strategies and practices. Furthermore, future research can examine the potential differences in the relationship between specific stakeholder-targeted CSR activities and financial performance, since it is expected (at least by the shareholders) that the scarce resources of the company will be allocated in the optimal way for the interest of the organization (Mitchell et al. 2017; Orlitzky et al. 2017; Ni et al. 2015; Tuppura et al. 2016; Peloza and Shang, 2011).

\section{References}

Aguinis, H. and Glavas, A. (2012), "What we know and don't know about corporate social responsibility a review and research agenda", Journal of Management, Vol. 38 No. 4, pp. 932-968.

Anadol, Y., Youssef, M., A. and Thiruvattal, E. (2015), „Consumer reaction towards corporate social responsibility in United Arab Emirates", Social Responsibility Journal, Vol. 11 No. 1, pp. 19-35.

Aras, G, Aybars, A. and Kutlu,O. (2010), „Managing corporate performance: Investigating the relationship between corporate social responsibility and financial performance in emerging markets", International Journal of Productivity and Performance Management, Vol. 59 No. 3 , pp.229-254.

Baba, S., and Raufflet, E. (2017), „Challenging Stakeholder Salience: Lessons from Dormant Local Stakeholders", in Wasieleski, D., M. and Weber, J. Stakeholder Management, Business and Society 360, Vol. 1, pp. 159-188.

Beckman, T., Khare, A. and Matear M. (2016), „Does the theory of stakeholder identity and salience lead to corporate social responsibility? The case of environmental justice", Social Responsibility Journal, Vol. 12 No. 4, pp. 806-819.

Berelson, B. (1952), Content analysis in communication research. New York, NY, US: Free Press.

Beaulieu, S., and Pasquero, J. (2002), „Reintroducing stakeholder dynamics in stakeholder thinking: A negotiated order perspective", Journal of Corporate Citizenship, Vol. 6, pp. 53-69.

Brammer S., Millington A., Rayton B. (2007), The Contribution of Corporate Social Responsibility to Organizational Commitment, International Journal of Human Resource Management, No. 18(10), pp. 1701-1719.

Carroll, A., B., and Shabana, K. M. (2010), „The business case for corporate social responsibility: A review of concepts, research and practice", International Journal of Management Reviews, Vol. 12 No. 1, pp. 85-105.

Cascio, W. and Aguinis, H. (2008), „Research in industrial and organizational psychology from 1963 to 2007: changes, choices, trends", Journal of Applied Psychology, Vol. 93 No. 5, pp. 1061-1081. 
Chang, K., Nguyen, B., Cheng, K. T., Kuo, C., C. and Lee, I. (2016), „HR practice, organisational commitment \& citizenship behaviour A study of primary school teachers in Taiwan", Employee Relations, Vol. 38 No. 6, pp. 907-926.

Chaudhary, R. (2017), „,Corporate social responsibility and employee engagement: can CSR help in redressing the engagement gap?" Social Responsibility Journal, Vol. 13 No. 2, pp. 323-338.

Cordeiro, J., J. and Tewari, M. (2015), „Firm Characteristics, Industry Context, and Investor Reactions to Environmental CSR: A Stakeholder Theory Approach", Journal of Business Ethics, 130:833-849.

Dias, A., Rodrigues, L., L and Craig, R. (2016), „Global financial crisis and corporate social responsibility disclosure", Social Responsibility Journal, Vol. 12 Issue: 4, pp.654-671.

Diaz-Pond, J. (2017), „Mapping the Changes of CSR Stakeholder Perceptions in a Context of Economic Depression in Spain: An Approach from Communication and Governance", Corporate Social Responsibility and Corporate Governance, Published online: 27 Jun 2017, pp. 89-110.

Du, S., Bhattacharya, C.B. and Sen, S. (2010), „Maximizing Business Returns to Corporate Social Responsibility (CSR): The Role of CSR Communication", International Journal of Management Reviews, Vol. 12 No. 1, pp. 8-19.

EC (2014), SBA Fact Sheet - Greece.

Eisenegger, M and Schranz, M. (2011), „Reputation Management and Corporate Social Responsibility", in: Oyvind Ihlen, Jennifer Bartlett und Steve May (Hrsg.), The Handbook of Communication and Corporate Social Responsibility, Chichester: Wiley-Blackwell, S. 128-146.

Fehre, K. and Weber, F. (2016), "Challenging corporate commitment to CSR: Do CEOs keep talking about corporate social responsibility (CSR) issues in times of the global financial crisis?" Management Research Review, Vol. 39 No 11, pp.1410-1430.

Souto, Fernandez-Feijoo, B. (2009), „Crisis and Corporate Social Responsibility: Threat or Opportunity?" International Journal of Economic Sciences and Applied Researches, Vol. 1 No. 1 pp. 36-50.

Ferreira, D. A. Avila, M. G. and de Faria, M. D. (2010), „Corporate social responsibility and consumers' perception of price", Social Responsibility Journal, Vol. 6 No. 2, pp. 208-221.

Freeman, R., E. (1984), Strategic management: A stakeholder approach, Boston: Pitman.

Freeman, R., E. and Mcvea, J., F. (2001), „A Stakeholder Approach to Strategic Management”, SSRN Electronic Journal, available at: http://papers.ssrn.com/paper.taf?abstract_id=263511, (accessed 20 September 2016).

Friedman, M. (1970), "The social responsibility of business is to increase its profits”, New York Times Magazine, p. 33.

Fukukawa K., Balmer J.M.T., Gray E.R. (2007) Mapping the Interface Between Corporate Identity, Ethics and Corporate Social Responsibility, Journal of Business Ethics, No. 76, pp. 76-98. 
García-Benau, M., A., L Sierra-Garcia, A., L. and Zorio, A. (2013), „Financial crisis impact on sustainability reporting", Management decision, Vol. 51, No. 7, pp. 1528-1542.

Giannarakis, G. and Theotokas, I. (2011), , The effect of financial crisis in corporate social responsibility performance", International Journal of Marketing Studies, Vol. 3 No. 1, pp. 2-10.

Guerci, M., and Shani, A. B. (2013), „Moving toward stakeholder-based HRM: A perspective of Italian HR managers", International Journal of Human Resource Management, Vol. 24 №. 6 , pp. 1130-1150.

Hellenic Statistical Authority (2017), Research on Human Resources (Press release) http:/l www.statistics.gr/documents/20181/007b1bab-7cad-4df3-81f1-5b18c76770ce, (accessed on March 1, 2017).

Holcomb, J. L. Upchurch, R. S., and Okumus, F. (2007), „Corporate social responsibility: what are top hotel companies reporting?", International Journal of Contemporary Hospitality Management, Vol. 19 No. 6, pp. 461-475.

loannou, I. and Serafeim, G. (2012), „What drives corporate social performance? The role of nation-level institutions", Journal of International Business Studies, Vol. 43 No. 9, pp. 834-864.

Karaibrahimoglu, Y. (2010), „Corporate social responsibility in times of financial crisis”, African Journal of Business Management, Vol. 4 No. 4, pp. 382-389.

Karagiorgos, T. (2010), "Corporate social responsibility and financial performance: An empirical analysis on Greek companies", European Research Studies, Vol. 13 No 4, pp. 85-110.

Kavoura, A. and Sahinidis, A. G. (2015), „Communicating Corporate Social Responsibility Activities in Greece in a period of a prolonged economic crisis", Proceedings of the 3rd International Conference on Strategic Innovative Marketing; 1-4 September, Madrid: Elsevier Procedia 175, 496-502.

Kim H.R., Lee M., Lee H.T., Kim N.M. (2010), Corporate Social Responsibility and EmployeeCompany Identification, Journal of Business Ethics, No. 95, pp. 305-314

Lee, J. H. (2015), „Stakeholder work and value creation stakeholder engagement: An integrative framework". Unpublished doctoral dissertation. Texas TechUniversity, Lubbock, TX.

Levitt, T. (1958), „The dangers of social-responsibility”, Harvard Business Review, Vol. 36 No. 5 , pp. 41-50.

Magness, V. (2008), „Who are the stakeholders now? An empirical examination of the Mitchell, Agle, and Wood theory of stakeholder salience", Journal of Business Ethics, Vol. 83 №. 2, pp. 177-192.

Matten, D. and Moon, J. (2008), „Implicit and explicit CSR: A conceptual framework for understanding CSR in Europe", Academy of Management Review, Vol. 33 No. 2, pp. 404-424.

Metaxas, M., Tsavdaridou, M. (2013), „CSR in metallurgy sector in Greece: A content analysis”, Resources Policy, Vol. 38 pp. 295-309

Minor, M. and Morgan, J. (2011), „CSR as Reputation Insurance: Primum Non Nocere”, California Management Review, Vol. 53 No. 3, pp. 40-59. 
Mitchell, R.K., Agle, B.R. and Wood, D.J. (1997), „Toward a theory of stakeholder identification and salience: defining the principle of who and what really counts", Academy of Management Review, Vol. 22 No. 4, pp. 853-886.

Mitchell, R.K., Jae Hwan Lee, J., H and Agle, B., R. (2017), „Stakeholder Prioritization Work: The Role of Stakeholder Salience in Stakeholder Research", in: Wasieleski, D., M. and Weber, J. Stakeholder Management, Business and Society 360, Vol. 1, 123-157.

Nag, T. and Bhattacharyya, A. K. (2016), „Corporate Social Responsibility Reporting in India: Exploring Linkages with Firm Performance", Global Business Review, Vol 17 No. 6, pp. 1427-1440.

Neville, B.A., Bell, S.J. \& Whitwell, G.J. (2011), „Stakeholder Salience Revisited: Refining, Redefining, and Refueling an Underdeveloped Conceptual Tool", Journal of Business Ethics, Vol. 102, No. 3, pp. 357-378.

Ni, N., Egri, C., Lo, C. and Lin, C. Y. Y. (2015), „Patterns of corporate responsibility practices for high financial performance: Evidence from three Chinese societies", Journal of Business Ethics, Vol. 126 No. 2, pp. 169-183.

Orlitzky, M., Schmidt, F. L., and Rynes, S. L. (2003), „Corporate social and financial performance: a meta-analysis", Organization Studies, Vol. 24 No. 3, pp. 403-441.

Orlitzky, M., Louche, C. Gond, J. C. Chapple C. (2017), „Unpacking the Drivers of Corporate Social Performance: A Multilevel, Multistakeholder, and Multimethod Analysis", Journal of Business Ethics, 144:21-40.

Peloza, J. and Shang, J. (2011), „How can corporate social responsibility activities create value for stakeholders? A systematic review", Journal of the Academy of Marketing Science, Vol. 39 No. 1, pp. 117-135.

Peloza, J., \& Papania, L. (2008), „The missing link between corporate social responsibility and financial performance: stakeholder salience and identification", Corporate Reputation Review, Vol. 11 No. 2, pp. 169-181.

Porter, M.E. and Kramer, M.R (2006), „Strategy and society: The link between competitive advantage and corporate social responsibility", Harvard Business Review, Vol. 84 No. 12, pp. 78-92.

Porter, M. E., and Kramer, M. R. (2011), „Creating shared value”, Harvard Business Review, Vol. 89 No. 1, pp. 62-77.

Placier, K., (2011), ,The Impact of Recession on the Implementation of Corporate Social Responsibility in Companies", Journal of Competitiveness, No. 2, pp. 83-98.

Reklitis, P., Trivellas, P., Mantzaris, I., Mantzari, E. and Reklitis D. (2018), „Employee Perceptions of Corporate Social Responsibility Activities and Work-Related Attitudes: The Case of a Greek Management Services Organization", in: Gal, G., Akisik, O., Wooldrodge, W. eds., Sustainability and Social Responsibility: Regulation and Reporting, pp. 225-241, Springer.

Rupp D.E., Ganapathi J., Aguilera R.V., Williams C.A. (2006), Employee Reactions to Corporate Social Responsibility: An Organizational Justice Framework. Journal of Organizational Behavior, No. 27(4). 
Sahinidis, A. G., Daskalaki, D., Mantzari, E., and Mantzaris, I. (2018), „The impact of the economic crisis on the Corporate Social Responsibility activities of Greek companies", in: Gal, G., Akisik, O., Wooldrodge, W. eds., Sustainability and Social Responsibility: Regulation and Reporting, pp. 241-260, Springer.

Sahinidis, A., G., and Kavoura, A. (2014), „Exploring Corporate Social Responsibility practices of Greek companies", The Małopolska School of Economics in Tarnów Research Papers Collection, Vol. 24 No. 2, pp. 185-193.

Skouloudis, A., Chymis, A., Stuart, A. and Evangelinos, K. (2014), „Corporate social responsibility: a likely causality of the crisis or a potential exit strategy component? A proposition development for an economy under pressure", Social Responsibility Journal, Vol. 10 Issue: 4, pp.737-755.

Schwartz, M. and Carroll, A. B. (2008), ,Integrating and Unifying Competing and Complementary Frameworks: The search for a common core in the business and society field", Business and Society, Vol. 47, pp. 148-186.

Shiu, Y. M. and Yang, S. L. (2017), „Does engagement in corporate social responsibility provide strategic insurance-like effects?" Strategic Management Journal, Vol. 38, pp. 455-470.

Taghian, M., D'Souza, C. and Polonsky, M. (2015), „A stakeholder approach to corporate social responsibility, reputation and business performance", Social Responsibility Journal, Vol. 11 No. 2, pp. 340-363.

Thijssens, T., Bollen, L. and Hassink, H. (2015), „Secondary Stakeholder Influence on CSR Disclosure: An Application of Stakeholder Salience Theory", Journal of Business Ethics, Vol. 132, No. 4, pp. 873-891.

Tuppura, A., Arminen, H., Pätäri, S. and Jantunen, A. (2016), „Corporate social and financial performance in different industry contexts: the chicken or the egg?", Social Responsibility Journal, Vol. 12 Issue: 4, pp.672-686.

Vitaliano, D. F. (2010), "Corporate social responsibility and labour turnover”, Corporate Governance: The International Journal of Business in Society, Vol. 10 No. 5, pp.563-573.

Wang, Q., Dou, J., and Jia, S. (2016), ,A Meta-Analytic Review of Corporate Social Responsibility and Corporate Financial Performance the Moderating Effect of Contextual Factors", Business and Society, Vol. 55 No. 8, pp. 1083-1121.

Wang, H., Tong, L., Takeuchi, R., and George, G. (2016), „Corporate Social Responsibility: An Overview and New Research Directions: Thematic Issue on Corporate Social Responsibility", Academy of Management Journal Vol. 59 No. 2, pp. 534-544.

Weitzner, D. and Deutsch, Y. (2015), Understanding Motivation and Social Influence in Stakeholder Prioritization, Organization Studies, Vol. 36, No. 10, pp. 1337-1360.

Yoon, J and Lee, S. (2016), „What Makes Employees Zealous Supporters of Their Firm's CSR Initiative? The Role of Employees' Perceptions of Their Firm's CSR Authenticity", Advances in Group Processes. Published online, pp. 93-126. 